DIGITAL COMMONS
@ UNIVERSITY OF SOUTH FLORIDA

Volume 7

Issue 1 Volume 7.1 (Spring 2017)

\section{ABO: Interactive Journal for Women in the Arts, 1640-1830}

\title{
Embodying Gender and Class in Public Spaces through an Active Learning Activity: "Out and About in the Eighteenth Century"
}

Ann Campbell

Boise State University, anncampbell@boisestate.edu

Follow this and additional works at: https://digitalcommons.usf.edu/abo

Part of the Educational Methods Commons, Feminist, Gender, and Sexuality Studies Commons, and the Literature in English, British Isles Commons

\section{Recommended Citation}

Campbell, Ann (2017) "Embodying Gender and Class in Public Spaces through an Active Learning Activity: "Out and About in the Eighteenth Century"," ABO: Interactive Journal for Women in the Arts, 1640-1830:

Vol.7: Iss.1, Article 7.

http://doi.org/10.5038/2157-7129.7.1.1136

Available at: https://digitalcommons.usf.edu/abo/vol7/iss1/7

This Pedagogy is brought to you for free and open access by Digital Commons @ University of South Florida. It has been accepted for inclusion in ABO: Interactive Journal for Women in the Arts, 1640-1830 by an authorized administrator of Digital Commons @ University of South Florida. For more information, please contact digitalcommons@usf.edu. 


\title{
Embodying Gender and Class in Public Spaces through an Active Learning Activity: "Out and About in the Eighteenth Century"
}

\author{
Abstract \\ This article explains how and why the learning activity "out and about in the eighteenth century" fosters \\ students' understanding of historical and cultural issues related to gender and class in eighteenth-century \\ novels. \\ Creative Commons License \\ cc) (1) $\odot$
}

This work is licensed under a Creative Commons Attribution-No Derivative Works 3.0 License. 


\section{Introduction to $A B O$ 's Teaching Forum}

Cynthia Richards, Pedagogy Editor

This issue inaugurates the first of $A B O$ 's Teaching Forums. These forums feature a series of shorter essays that are in conversation with one another about issues related to teaching all aspects of women in the arts in the long eighteenth century. Geared to a scholarly audience, these forums may be both practical and theoretical in nature, but will uniformly take as their focus the public work of the classroom and how scholarship is translated into action. These first four essays illustrate that focus by foregrounding practices in which students are asked-sometimes quite literally—to embody knowledge of the eighteenth century, and particularly, how gender reframes that experience. As such, they speak to the long-standing feminist practice that acknowledges the role of the body in shaping experience and point to emerging insights in Body Studies, which focus on a history of the body and its representation.

Listed chronologically in terms of content, the four essays included in the forum are: "Arabella's Valentines and Literary Connections [dot] com: Playing with Eighteenth-century Gender Online" by Melanie Holm; "Less of the Heroine than the Woman: Parsing Gender in the British Novel" by Susan Carlile; "Embodying Gender and Class in Public Spaces through an Active Learning Activity: Out and About in the Eighteenth Century" by Ann Campbell; and "Embodying Character, Adapting communication; or, the Senses and Sensibilities of Epistolarity and New Media in the Classroom" by Jodi L. Wyett. Embodying Gender and Class in Public Spaces through an Active Learning Activity: "Out and About in the Eighteenth Century"

Embodying Gender and Class in Public Spaces through an Active Learning Activity: "Out and About in the Eighteenth Century"

\section{Overview}

One of my favorite scenes to teach in all of eighteenth-century British literature is the private ball depicted by Frances Burney in the opening pages of Evelina (1778). A newcomer to society, Evelina joins her wealthy and socially prominent hosts at a private ball in London. Ignorant of how to behave and unused to high society, she proceeds to violate just about every possible social code. While this is a delightful scene to teach and always appeals to students once they understand it, it exemplifies one of the two problems the learning activity "Out and About in the Eighteenth Century" is intended to address: how essential it is for students of eighteenthcentury literature to understand conventions associated with gender and class, and how difficult it is to assess or reward this knowledge. 
In order to comprehend the private ball scene in Evelina students must first know all of the following information: surnames confer status and legitimacy; young unmarried women should not turn down one partner and accept another; young women must remain with their dance partners for an allotted time and act according to a set of prescribed rules of conduct during that time; and certain types of behavior, such as laughing, violate both class and gender conventions. Only once students understand these and numerous other unspoken rules about social codes can they even begin to interpret eighteenth-century literature. However, as professors we design most of our assignments, critical and research essays in particular, to assess students' skill and grace as interpreters of literature and culture. We assume that understanding what happens in a novel like Evelina is merely a precursor to analyzing how and why it happens.

Learning activities such as "Out and About in the Eighteenth Century" provide a way to reinforce, enact and assess students' understanding of eighteenthcentury class and gender norms, redressing this misalignment between what we expect students to know and what we typically design courses to assess. In this particular activity, students act the parts of eighteenth-century literary characters interacting with other literary characters at several public venues. "Out and About in the Eighteenth Century" is similar to Melanie Holm's "Literary Connections.com" activity and Jodi Wyett's "Text, Tweet, Write" exercise because all three of them require students to embody characters from eighteenth-century novels. Unlike quizzes or exams, each of these learning activities encourages students to engage creatively with history and literature. They are also enormously fun.

\section{The Activity}

"Out and About in the Eighteenth Century" is designed to synthesize and enact students' cumulative knowledge about class, gender and eighteenth-century public places during the final class session of the semester in a 300-level undergraduate eighteenth-century novel course. It could be adapted to fit a variety of period-based courses focusing on place-based narratives. However, it works best for novels, and specifically for comic or social novels, because they typically include scenes set in public places as well as numerous male and female characters from a variety of classes. The version I explicate here is tailored to my syllabus, which covers Daniel Defoe's Moll Flanders (1722), Samuel Richardson's Pamela (1740), Henry Fielding's Tom Jones (1749), and Evelina. Each student acts the part of a character from these novels, visiting four London venues that appear in at least one of them. In order to successfully perform their parts each student must take into account his or her character's age, gender, class, education and urbanity (or lack thereof). Also, students must know enough about each venue to act appropriately when visiting it. My intent in devoting the final class session of the semester to this activity is for 
students to perform their cumulative knowledge of eighteenth-century literature and culture, especially with regards to gender and class.

In practical terms, the activity works as follows. Prepare students for the activity in the prior class session by holding a lottery in which they draw their characters. I typically include these characters in the lottery: the governess, the husband-brother, and Moll from Moll Flanders; Pamela, Mrs. Jewkes, Lady Davers and Mr. B. from Pamela; Squire Western, Molly Seagrim, Tom Jones, Blifil, Mr. Allworthy, Thwackum, Square and Sophia from Tom Jones; and Evelina, Mr. Villars, Lord Orville, Sir Clement, Mrs. Selwyn, Madame Duval, Mr. Macartney, Tom Branghton and Mr. Lovel from Evelina. The sheer number of characters is best accommodated by a class of at least fifteen, but the activity itself requires so much moving around and discussion that it is difficult to direct in a class bigger than twenty-five. I do not assign roles based on students' gender, a practical decision (most of my students are women) that also has strategic advantages since by embodying a different gender students experience the limitations imposed on women and the privileges granted to men. The characters you select for the activity need to speak enough for students to model their speech patterns on conversations that occur in the novels. Also, it helps if you choose characters with marked personality traits. For instance, it is easy to act out a character such as Madame Duval because she peppers her speech with misapplied French phrases such as $m a$ foi and behaves outrageously. While the number of students often necessitates the inclusion of duller characters such as Mr. Villars or Mr. Macartney, the activity will be more enjoyable if you exhaust vibrant ones first.

On the day of the activity, students enter class in character and join one of the four venues located at each corner of the classroom and identified with appropriate objects (like a tankard for the tavern or a mask for the masquerade) and signs. I provide in each corner an equal number of chairs and try to make all four locations approximately the same size. I inform students in advance what these venues will be so they can prepare ahead of time to act appropriately in each of them. The venues I use most frequently are as follows: a dinner box at Vauxhall; the refreshment room of Drury Lane Theatre; a tavern; and a public masquerade. I select these particular spaces because people from different classes and professions congregated in them. Although in reality parties would self-select even at these locations to exclude strangers and people from different class backgrounds, they provide a legitimate reason for a motley group of characters culled from different novels to conceivably converge in the same place. For the purposes of the activity, I also ignore historical proscriptions against, for example, respectable women in a tavern.

When visiting a venue, students suit their topics of conversation to the norms of the place as well as their character's interests, gender, social background, education, class, and level of urbanity. While certain characters such as Squire 
Western will only be at home in one venue (the tavern in his case), others such as Lord Orville are universally polite, and will thus shine equally everywhere. Students remain in character and continue circulating for about an hour of a seventy-five minute class period, leaving the remaining fifteen minutes for discussion or revealing their identities. The minimum time you would want to allocate to the activity is forty-five minutes since it takes at least fifteen minutes for most students to become comfortable adopting their literary personas. In order to facilitate movement from venue to venue, I require they visit each one and stay for at least five minutes. Because I run the activity for an hour and expect students to speak to all their classmates at least once, they almost always return to venues several times over the course of the class period. In order to encourage mingling I also place limits on the number of students per venue at any one time. However, the crowding which occurs at overpopulated venues is often more effective than explicit prohibitions at preventing larger groups of students from loitering together in one place. The conversations students engage in during the activity reflect their cumulative knowledge of how age, gender, class and education affect characters' ability to converse on particular topics or conform to the conventions associated with public spaces depicted frequently in eighteenth-century novels.

\section{Goals of the Activity}

The central premise of a learning activity such as "Out and About in the Eighteenth Century" is that it is more powerful to show than to tell. By trying to embody characters in the novels we read, students discover for themselves the ways eighteenth-century conventions and habits of sociability created invisible barriers between men and women, people in different classes, the married and unmarried, urban and rural dwellers, and the old and young. Molly Seagrim would fit awkwardly into a group of Lord Orville's companions strolling about Vauxhall. Her lack of status, education, and money, as well as her confined life in the country, would make it almost impossible for her to converse gracefully about literature and public places. Her overt sexuality also violates norms for unmarried women in polite society. All these things seem obvious based on even a cursory reading of Tom Jones and Evelina. However, even if students understand theoretically the ways conventions reinforced gender and class boundaries, it is revelatory to experience it.

Even today, it is one thing to know money creates social divisions, and another thing to try to fit into a space for which you are socioeconomically unprepared. For example, I learned more about class by visiting as a guest the Charleston Yacht Club in Charleston, South Carolina than by reading Thomas Piketty's Capital in the Twenty-First Century. Or rather, the whole of intellectual and practical experience is greater than the sum of its parts; by intellectually superimposing what I learned from Piketty onto my experience at the Yacht Club I 
learned more about class than either reading or experience alone could teach. Students will make similar connections to class- and gender-coded spaces they have experienced in their own lives, creating fertile ground for discussions about how vestigial aspects of eighteenth-century conventions persist today.

\section{Assessment}

Students don't necessarily share my lofty didactic goals, so I motivate them to prepare thoroughly for and participate enthusiastically in this activity by presenting it as a game, the object of which is to correctly guess the identities of their classmates. Students are not supposed to reveal the characters they draw to anyone but me. They wear nametags with their actual names during the activity and carry around a sheet with the names of all the characters impersonated by members of the class. By conversing with each of their classmates in the various venues they must surmise who each one is supposed to be. During the final fifteen minutes of class they reveal their own characters and count up how many of their classmates' identities they correctly surmised. Describing this activity as a game and offering some sort of reward, usually an extra credit point, for identifying all the other students' eighteenth-century identities inspires students to treat the activity seriously. They all want to win, while only some of them want to successfully perform their characters for learning's sake.

Admittedly, there are some inherent disadvantages to this approach. Students ask questions meant to draw out their classmates' identities rather than to emulate real eighteenth-century conversation of the sort Lord Orville and Evelina participate in when they visit the Pantheon in Evelina. However, I have found as I experimented with different versions of the activity over the last ten years that the excitement fostered by competition is well worth any pedagogical sacrifice it entails. Some students even devise costumes because they want to "suit up" for the eighteenth-century "big game." Memorably, a pretended Mr. Lovel came to class with a Curious George doll attached to his ear. Strategically, identifying oneself visually is actually a disadvantage. However, this is just one example of how the game component of the activity creates its own momentum, animating and engaging students creatively in ways that exceed the logical boundaries of the game itself. Additionally, this competitive desire to unmask mirrors exactly the conditions of a masquerade ball, one of the four venues.

If you wish to integrate "Out and About in the Eighteenth Century" into your syllabus as a regular assignment rather than an extra-credit opportunity, there are numerous ways to do so. You could limit the activity to a particular novel such as Moll Flanders, altering the public places accordingly to reflect the content of the novel. (The four venues might become the Mint, the neighborhood Moll lives in when she meets her half-brother/husband, the Colchester Inn, and a London street scene.) This approach also allows you to integrate the activity earlier in the semester, 
thus encouraging students to reflect on it as they read other eighteenth-century texts together. Rather than base students' grades on their ability to guess others' identities - something they can't always control since even one poorly-prepared student can make it impossible for others to correctly identify him or her-you can create a rubric allotting specific points for each aspect of a student's performance. For example, if the activity is worth five percent of a student's grade on a hundredpoint scale, the rubric might look something like this:

\begin{tabular}{|l|l|}
\hline Requirements & Possible Points \\
\hline $\begin{array}{l}\text { Accurately responding } \\
\text { to questions based on the } \\
\text { novel's depiction of } \\
\text { your character }\end{array}$ & $\begin{array}{l}\text { 3= Strong (answered almost all questions accurately); } \\
\text { questions accurately); 1=Poor (answered at least one- } \\
\text { third of questions accurately); 0=No Credit (did not } \\
\text { respond accurately to any questions) }\end{array}$ \\
\hline $\begin{array}{l}\text { Followed conventions } \\
\text { associated with venues }\end{array}$ & $\begin{array}{l}\text { 2= Strong (consistently conversed according to } \\
\text { conventions for each venue); 1=Acceptable } \\
\text { (conversed according to conventions for specific } \\
\text { venues at least one-half of the time); 0= No Credit } \\
\text { (conversed according to conventions for each venue } \\
\text { one-third or less of the time) }\end{array}$ \\
\hline
\end{tabular}

There are two different ways of assessing students' performance in these categories. First, you could converse with each student at least once and base your assessment on this interaction. In this case you assume your interaction with each student is representative of his or her performance over the course of the class period. Second, you could ask students to evaluate one another, either formally by having them take notes on each interaction or informally by emailing you feedback about classmates whose performance was either exceptional or unsatisfactory. The obvious drawback to this approach is that it discourages collegiality since it positions students as potential adversaries. It is largely to avoid the problems implicit in both of these ways of grading the assignment that I treat it as extra credit.

\section{Further Suggestions:}

"Out and About in the Eighteenth Century" will be most successful if you articulate its rules ahead of time. First, clarify what version of the novels' characters students should impersonate. Protagonists frequently change over the course of a novel. The rakish Mr. B. at the outset of Pamela speaks differently about marriage and female virtue than his later married and domesticated incarnation. He would also answer factual questions such as whether he is married differently. The easiest way to overcome this difficulty is to specify that students portray characters from the perspective of the novels' conclusions. 
Second, establish rules of conduct. The classroom can become increasingly raucous as the activity proceeds and even shy students will often say and do things that are completely out of character. The student performing Mr. B. one year tried to force other students onto her lap while calling them "saucebox" and "speaking picture." If you want to prohibit touching or certain types of questions, do so ahead of time rather than trying to intervene once something like this happens. I prefer to allow students as much latitude as possible because it makes the activity more lively, humorous and spontaneous, but the degree of freedom you allow them depends largely on their maturity and your priorities as a teacher.

Third, announce whether costumes will be permitted. Otherwise, some students will wear them and some won't, and the ones who don't will resent missing out on the fun. Establishing these rules ahead of time anticipates and thus prevents the most frequent problems I have encountered with this activity. 